\title{
Consumptive Use of Water, Soil Moisture Use Rate and Water Productivity of Blackgram as Influenced by Foliar Nutrition under Limited Irrigation
}

\author{
Kaviti Vijaya Lakshmi*, S. Prathibha Sree, N. Venkata Lakshmi, \\ P. Madhu Vani and K. Chandrasekhar \\ Department of Agronomy (Water Management), Advanced post graduate centre, \\ Lam, Guntur-522034, India \\ *Corresponding author
}

\section{A B S T R A C T}

\begin{tabular}{|c|}
\hline Keywords \\
\hline $\begin{array}{l}\text { Blackgram, } \\
\text { Consumptive use of } \\
\text { water, Soil moisture } \\
\text { use rate, Water } \\
\text { productivity, Foliar } \\
\text { nutrition }\end{array}$ \\
\hline Article Info \\
\hline $\begin{array}{l}\text { Accepted: } \\
20 \text { May } 2018 \\
\text { Available Online: } \\
10 \text { June } 2018\end{array}$ \\
\hline
\end{tabular}

A field experiment was conducted on sandy loam soils of Agricultural Research Station, Jangamaheswarapuram during rabi, 2016-17. The experiment was laid out in split plot design and replicated thrice. The treatments comprised of four main plots viz., No irrigation $\left(\mathrm{I}_{1}\right)$, Irrigation at $0.3\left(\mathrm{I}_{2}\right), 0.4\left(\mathrm{I}_{3}\right)$ and $0.5 \mathrm{IW} / \mathrm{CPE}$ ratios $\left(\mathrm{I}_{4}\right)$ and four sub plot treatments viz., foliar spray of $2 \%$ urea $\left(\mathrm{F}_{1}\right), 2 \% \mathrm{DAP}\left(\mathrm{F}_{2}\right), 1 \% \mathrm{KNO}_{3}\left(\mathrm{~F}_{3}\right)$ and $2 \% 19-19-$ $19\left(\mathrm{~F}_{4}\right)$ twice at pre flowering pod filling stages. The results indicated that the consumptive use of water and daily soil moisture use rate were significantly affected by irrigation and foliar nutrition treatments and the highest were recorded with irrigation at $0.5 \mathrm{IW} / \mathrm{CPE}$ followed by 0.4 and $0.3 \mathrm{IW} / \mathrm{CPE}$ ratios. Among the foliar treatments, foliar spray with $2 \%$ DAP recorded the highest consumptive use and soil moisture use rate but on a par with 2 $\%$ urea twice at pre flowering and pod filling stages. The highest water productivity was recorded in control plot followed by 0.3 and 0.5 IW/CPE ratios coincided with pod filling (57 DAS) and pre flowering stages (33 DAS). The lowest was recorded with $0.4 \mathrm{IW} / \mathrm{CPE}$ coincided with pod formation stage (43 DAS). Foliar application of $1 \% \mathrm{KNO}_{3}$ recorded the highest water productivity which was significantly superior to other foliar treatments.

\section{Introduction}

Pulses are wonderful gift of nature with unique ability of biological nitrogen fixation, deep root system, mobilization of insoluble soil nutrients and bringing qualitative changes in soil properties. Blackgram (Vigna mungo L.), also known as urd bean, mash and black maple is a short duration pulse crop grown in many parts of India. It is one of the highly prized pulse crops with regard to its antiquity and its use as a source of human food. In
Andhra Pradesh, blackgram is grown in an area of 3.17 lakh ha with a production of 2.16 lakh tonnes and productivity of $866 \mathrm{~kg} \mathrm{ha}^{-1}$ during the year 2015-16 (Agriculture action plan 2015-16, Department of Agriculture, A.P). Water productivity is the cornerstone of any demand management strategy. Definition of water productivity is scale dependent. In Krishna-Godavari and North coastal zones of Andhra Pradesh, blackgram is mostly grown as a relay crop, where in sprouted seeds are broadcasted in standing rice crop two to three 
days before its harvest. The blackgram sown in this system survives entirely on residual moisture and fertility only. The traditional practice of broadcasting of seeds in the standing crop of rice does not ensure uniform plant population and severe weed infestation under zero tilled conditions deprives the crop of its major requirements of nutrients and moisture which results in poor crop growth and culminates yield loss up to an extent of 45 to 60 per cent. Water productivity can be analyzed at the plant level, field level, farm level, system level and basin level, and its value would change with the changing scale of analysis (Molden et al., 2001).

\section{Materials and Methods}

A field experiment was conducted during rabi, 2016-17 at Agricultural Research Station, Jangamaheswarapuram, Gurazala, Guntur district of Andhra Pradesh on sandy loam soil. The weekly mean maximum temperatures during crop period, 2016-17 ranged from $29.4^{\circ} \mathrm{C}$ to $33.9^{\circ} \mathrm{C}$ against the average of $32.3^{\circ} \mathrm{C}$. The mean minimum temperatures for the corresponding period were $20.2^{\circ} \mathrm{C}$ to $25.6^{\circ} \mathrm{C}$ as against the average of $22.2^{\circ} \mathrm{C}$. The weekly mean relative humidity ranged between 77.4 and 92.5 per cent with an average of 85.2 per cent (Table 1). A total rainfall of $240.4 \mathrm{~mm}$ was received during the crop growth period with 13 rainy days. The experiment was laid out in a split plot design and replicated thrice.

The main plot treatments comprising of No irrigation $\left(\mathrm{I}_{1}\right)$, Irrigation at $0.3 \mathrm{IW} / \mathrm{CPE}\left(\mathrm{I}_{2}\right)$, $0.4 \mathrm{IW} / \mathrm{CPE}\left(\mathrm{I}_{3}\right)$ and $0.5 \mathrm{IW} / \mathrm{CPE}$ ratios $\left(\mathrm{I}_{4}\right)$ and four sub plot treatments viz., foliar spray of $2 \%$ urea $\left(\mathrm{F}_{1}\right), 2 \%$ DAP $\left(\mathrm{F}_{2}\right), 1 \% \mathrm{KNO}_{3}\left(\mathrm{~F}_{3}\right)$ and 2\% 19-19-19 $\left(\mathrm{F}_{4}\right)$ twice at pre-flowering pod filling stages. PU-31 blackgram variety was sown on 20-09-2016 at a spacing of 30 $\mathrm{cm} \times 10 \mathrm{~cm}$. A common depth of $5 \mathrm{~cm}$ irrigation water was applied at each irrigation based on CPE values which were worked out for each irrigation schedule based on IW/CPE ratios. No irrigation was given to control plot $\left(\mathrm{I}_{1}\right)$. Irrigations were given to $\mathrm{I}_{2}, \mathrm{I}_{3}$ and $\mathrm{I}_{4}$ treatments when the CPE values reached to $166.66 \mathrm{~mm}, 125 \mathrm{~mm}$ and $100 \mathrm{~mm}$, respectively. Consumptive use of blackgram was estimated thermo gravimetrically taking soil samples before and after each irrigation up to a depth of $60 \mathrm{~cm}$ in four layers consisting of $0-15,15-30,30-45$ and $45-60 \mathrm{~cm}$ as described by Dastane, 1967. The daily moisture use rate $\left(\mathrm{mm} \mathrm{day}^{-1}\right)$ was worked out from the soil moisture depleted from the root zone during the given sampling interval and the number of days in the interval. Crop water productivity needs to be assessed in terms of both kilogram of crop per cubic metre of water diverted or depleted $\left(\mathrm{kg} \mathrm{m}^{-3}\right)$ and net or gross present value of the crop produced per cubic metre of water (Kijne et al., 2003).

\section{Results and Discussion}

\section{Consumptive use of water}

The influence of irrigation and foliar nutrition treatments on consumptive use of water was found to be significant. Irrigation at 0.5 IW/CPE recorded the highest consumptive use of water $(225.3 \mathrm{~mm})$ which was significantly superior to other treatments. Among sub plot treatments, the highest consumptive use of water (Table 3) was recorded with foliar spraying of $2 \%$ DAP (189.8 mm) which was on a par with $2 \%$ urea $(188.8 \mathrm{~mm})$ and the lowest was recorded by application of $2 \% 19$ 19-19 (173.3 mm) which was comparable with $1 \% \mathrm{KNO}_{3}(175.2 \mathrm{~mm})$. The interaction effect of irrigation levels and foliar nutrition treatments on consumptive use of water was found to be non-significant. The increase in consumptive use of water might be due to optimum soil moisture availability and foliar spraying of water soluble fertilizers at critical stages of crop growth stages. Similar results 
were recorded by Ravindran nayar and Singh (1985) and Gaur and Choudhary (1993).

\section{Soil moisture use rate}

Irrigation at 0.5 IW/CPE ratio recorded significantly the highest soil moisture use rate (Table 3) $(3.04 \mathrm{~mm})$ followed by $0.4 \mathrm{IW} / \mathrm{CPE}$ and $0.3 \mathrm{IW} / \mathrm{CPE}$ ratios $(2.77$ and $2.05 \mathrm{~mm}$, respectively). The highest soil moisture use rate was recorded in the plots those received foliar spray with $2 \%$ DAP $(2.53 \mathrm{~mm})$. However, foliar spray with $2 \%$ DAP and $2 \%$ urea $(2.51 \mathrm{~mm})$ were at par with each other and significantly superior over foliar spray with $1 \% \mathrm{KNO}_{3}(2.33 \mathrm{~mm})$ and $2 \% 19-19-19$ $(2.31 \mathrm{~mm})$. The interaction effect of irrigation treatments and foliar nutrition on moisture use rate of blackgram, was found to be nonsignificant. Similar results in chickpea were reported by Ravindran nayar and Singh (1985) and Prabhakar and Saraf (1991).

Table.1 Weather data averaged weekly during the period of blackgram crop (17.09.2016 to 16.12.2016)

\begin{tabular}{|c|c|c|c|c|c|c|}
\hline \multirow[t]{2}{*}{$\begin{array}{l}\text { Standard } \\
\text { Meteorologic } \\
\text { alweek }\end{array}$} & \multirow[t]{2}{*}{ Date and Month } & \multicolumn{2}{|c|}{$\begin{array}{c}\text { Mean } \\
\text { Temperature } \\
\left({ }^{\circ} \mathrm{C}\right)\end{array}$} & \multirow{2}{*}{$\begin{array}{l}\text { Me } \\
\text { an } \\
\text { RH } \\
(\%)\end{array}$} & \multirow{2}{*}{$\begin{array}{c}\text { Actual } \\
\text { Rainfall } \\
(\mathbf{m m}) \\
(\mathbf{2 0 1 6})\end{array}$} & \multirow{2}{*}{$\begin{array}{c}\text { Normal } \\
\text { Rainfa } \\
\text { ll } \\
(\mathbf{m m}) \\
(1988- \\
2016)\end{array}$} \\
\hline & & Max. & Min. & & & \\
\hline 38 & Sep 17 - 23 Sep 2016 & 32.4 & 24.4 & 87.8 & 172.5 & 63.0 \\
\hline 39 & Sep 24 - 30 Sep 2016 & 32.5 & 24.1 & 88.0 & 14.4 & 36.0 \\
\hline 40 & Oct $01-07$ Oct 2016 & 33.9 & 25.6 & 79.7 & 6.8 & 49.6 \\
\hline 41 & Oct $08-14$ Oct 2016 & 33.6 & 25.4 & 89.3 & 45.3 & 21.5 \\
\hline 42 & Oct $15-21$ Oct 2016 & 33.1 & 22.1 & 80.3 & - & 14.0 \\
\hline 43 & Oct $22-28$ Oct 2016 & 33.7 & 21.2 & 77.4 & - & 26.7 \\
\hline 44 & Oct $29-04$ Nov 2016 & 32.4 & 22.4 & 81.0 & 0.3 & 35.5 \\
\hline 45 & Nov 05 - 11 Nov 2016 & 31.8 & 20.4 & 80.4 & - & $\overline{5.1}$ \\
\hline 46 & Nov $12-18$ Nov 2016 & 32.3 & 21.2 & 92.5 & - & 7.6 \\
\hline 47 & Nov $19-25$ Nov 2016 & 31.7 & 20.4 & 86.2 & - & 2.3 \\
\hline 48 & Nov 26 - 02 Dec 2016 & 32.0 & 20.7 & 85.0 & - & 3.2 \\
\hline 49 & Dec $03-09$ Dec 2016 & 31.0 & 20.2 & 90.5 & 1.1 & 6.7 \\
\hline 50 & Dec 10 - 16 Dec 2016 & 29.4 & 20.7 & 90.0 & - & 2.3 \\
\hline Total & & 419.8 & 288.8 & 1108.1 & 240.4 & 273.5 \\
\hline Mean & & 32.3 & 22.2 & 85.2 & & \\
\hline
\end{tabular}


Table.2 Water productivity $\left(\mathrm{kg} \mathrm{m}^{-3}\right)$ of blackgram as influenced by foliar nutrition under limited irrigation

\begin{tabular}{|c|c|c|c|c|c|c|}
\hline \multirow{3}{*}{\multicolumn{2}{|c|}{$\begin{array}{c}\text { Irrigation levels } \\
\text { (I) }\end{array}$}} & \multicolumn{4}{|c|}{ Water productivity $\left(\mathrm{kg} \mathrm{m}^{-3}\right)$} & \multirow[t]{3}{*}{ Mean } \\
\hline & & \multicolumn{4}{|c|}{ Foliar spray (F) } & \\
\hline & & $\begin{array}{c}F_{1} \\
(2 \% \text { Urea) }\end{array}$ & $\begin{array}{c}F_{2} \\
(2 \% \text { DAP })\end{array}$ & \begin{tabular}{cl}
\multicolumn{1}{c}{$\mathrm{F}_{3}$} \\
$\left(1 \% \mathrm{KNO}_{3}\right)$
\end{tabular} & $\begin{array}{c}\mathrm{F}_{4} \\
(2 \% 19-19-19)\end{array}$ & \\
\hline $\mathbf{I}_{1}$ & Control & 0.42 & 0.50 & 0.52 & 0.48 & 0.48 \\
\hline $\mathbf{I}_{2}$ & $0.3 \mathrm{IW} / \mathrm{CPE}$ ratio & 0.41 & 0.42 & 0.48 & 0.42 & 0.43 \\
\hline $\mathbf{I}_{3}$ & $0.4 \mathrm{IW} / \mathrm{CPE}$ ratio & 0.34 & 0.35 & 0.41 & 0.43 & 0.38 \\
\hline $\mathbf{I}_{4}$ & $0.5 \mathrm{IW} / \mathrm{CPE}$ ratio & 0.36 & 0.42 & 0.51 & 0.42 & 0.43 \\
\hline \multirow{2}{*}{\multicolumn{2}{|c|}{ Mean }} & 0.38 & 0.42 & 0.48 & 0.44 & \\
\hline & & SEm \pm & $C D(p=0.05)$ & CV $(\%)$ & & \\
\hline \multicolumn{2}{|c|}{ Irrigation levels (I) } & 0.01 & 0.03 & 5.9 & & \\
\hline \multicolumn{2}{|c|}{ Foliar spray (F) } & 0.01 & 0.03 & 7.1 & & \\
\hline \multicolumn{2}{|c|}{ Interaction } & 0.02 & NS & & & \\
\hline
\end{tabular}

Table.3 Influence of foliar nutrition on seed yield, consumptive use of water and soil moisture use rate of blackgram under limited irrigation

Treatment

Seed yield

$\left(\mathrm{kg} \mathrm{ha}^{-1}\right)$
Consumptive use of water (mm)
Soil moisture use rate $\left(\mathrm{mm} \mathrm{day}^{-1}\right)$

\section{Irrigation levels:}

$\mathrm{I}_{1}$-Control

$\mathrm{I}_{2}-0.3 \mathrm{IW} / \mathrm{CPE}$ ratio

610

710

790

959

I $4-0.5 \mathrm{IW} / \mathrm{CPE}$ ratio

$\mathrm{SEm} \pm$

$\mathrm{CD}(\mathrm{p}=0.05)$

$\mathrm{CV}(\%)$

Foliar spray:

$\mathrm{F}_{1}-2 \%$ urea

$\mathrm{F}_{2}-2 \%$ DAP

$\mathrm{F}_{3}-1 \% \mathrm{KNO}_{3}$

$\mathrm{F}_{4}-2 \%$ 19-19-19

$\mathrm{SEm} \pm$

$\mathrm{CD}(\mathrm{p}=0.05)$

$\mathrm{CV}(\%)$

Interaction $(\mathbf{I} \times \mathbf{F})$ :

$\mathrm{SEm} \pm$

$\mathrm{CD}(\mathrm{p}=0.05)$

704

782

833

749

23

67

10.4

46

NS
126.8

1.81

164.4

210.7

2.05

2.77

225.3

3.04

3.0

0.05

10.3

0.19

5.7

7.6
188.8

2.51

189.8

2.53

175.2

2.33

173.3

2.31

0.06

$\begin{array}{ll}4.1 & 0.06 \\ 11.7 & 0.18\end{array}$

7.6

8.8

8.1

0.12

NS

NS 


\section{Water productivity}

Among the different main plot treatments, non-irrigated plot recorded the highest water productivity $\left(0.48 \mathrm{~kg} \mathrm{~m}^{-3}\right)$ in blackgram (Table 2) which was significantly superior over $0.5 \mathrm{IW} / \mathrm{CPE}$ and $0.4 \mathrm{IW} / \mathrm{CPE}$ ratios. Irrigation at $0.3 \mathrm{IW} / \mathrm{CPE}$ ratio coincided with pod filling stage (57 DAS) and 0.5 IW/CPE ratio coincided with pre flowering stage (33 DAS) recorded water productivity of $0.43 \mathrm{~kg}$ $\mathrm{m}^{-3}$ which was significantly superior to 0.4 IW/CPE ratio coincided with pod formation stage (43 DAS).

Foliar spray with $1 \% \mathrm{KNO}_{3}$ recorded the highest water productivity $\left(0.48 \mathrm{~kg} \mathrm{~m}^{-3}\right)$ which was significantly superior to other foliar nutrition treatments. Foliar spray with 2 $\%$ 19-19-19 and $2 \%$ DAP were comparable with each other. The interaction effect of irrigation and foliar nutrition on water productivity was found to be non-significant.

Water productivity is used principally to evaluate the function of irrigation systems as the amount of 'crop per drop'. Highest water productivity in control plot might be due to production of relatively higher seed yields with minimum water use. This finding is in conformity with Shiva Dhar and Singh (1995) and Pramanik et al., (2009).

In conclusion, the study revealed that irrigation at $0.5 \mathrm{IW} / \mathrm{CPE}$ ratio and foliar spray of $1 \% \mathrm{KNO}_{3}$ twice at pre flowering and pod filling stages was found to be better in increasing the yield, consumptive use of water and water productivity of blackgram.

\section{References}

Agriculture action plan, 2015-16. Crop wise targeted area, productivity and production for 2015-16. Department of Agriculture, Andhra Pradesh. pp: 20.
Dastane, N.G. (1967). A practical manual for water use research in Agriculture. Navabharat Prakashan Publication. Poona, India. 5-6.

Gaur, B.L and Choudhary, M.K. (1993). Effect of irrigation and moisture conserving substances on yield and water-use efficiency of gram (Cicer arietinum L.). Indian Journal of Agricultural Sciences., 63(12):833-835.

Kijne, Jacob., Barker, R and Molden, D. (2003). "Water Productivity in Agriculture: Limits and Opportunities for Improvement, Comprehensive Assessment of Water Management in Agriculture". UK: CABI Publishing in Association with International Water Management Institute.

Molden, D., Sakthivadivel, R and Habib, Z. (2001). "Basin-Level Use and Productivity of Water: Examples from South Asia". IWMI Research Report 49. International Water Management Institute (IWMI), Colombo.

Prabhakar, M and Saraf, C.C. (1991). Effect of irrigation regimes and management of phosphorus sources on yield, biomass and water use of chickpea. Journal of Maharashtra Agricultural Universities., 16(2):221-223.

Pramanik, S.C., Singh, N.B and Singh, K.K. (2009). Yield, economics and water use efficiency of chickpea (Cicer arietinum L.) under various irrigation regimes on raised bed planting system. Indian Journal of Agronomy., 54(3):315-318.

Ravindran Nayar, R and Singh, N.P. (1985). Consumptive water use and soil moisture use pattern of late sown chickpea (Cicer arietinum L.) as influenced by irrigation and phosphorus. Indian Journal of Agronomy., 30(2): 192-198.

Shiva Dhar and Singh, N.P. (1995). Effect of irrigation schedules on yield attributes, consumptive use of water, water-use efficiency and moisture-extraction pattern of French bean (Phaseolus vulgaris L.). Indian Journal of Agronomy., 40(4):620625 . 


\section{How to cite this article:}

Kaviti Vijaya Lakshmi, S. Prathibha Sree, N. Venkata Lakshmi, P. Madhu Vani and Chandrasekhar, K. 2018. Consumptive Use of Water, Soil Moisture Use Rate and Water Productivity of Blackgram as Influenced by Foliar Nutrition under Limited Irrigation. Int.J.Curr.Microbiol.App.Sci. 7(06): 2419-2424. doi: https://doi.org/10.20546/ijcmas.2018.706.287 